\title{
Incremental Investment Value of Wild Turkey Management on the South Carolina Piedmont
}

\author{
Joseph D. Hammond1, Thomas J. Straka1, Tyler A. Brown² \\ ${ }^{1}$ Divison of Natural Resources, Clemson University, Clemson, SC, USA \\ ${ }^{2}$ National Wild Turkey Federation, Edgefield, SC, USA \\ Email: tstraka@clemson.edu
}

Received 1 July 2014; revised 6 August 2014; accepted 18 August 2014

Copyright (C) 2014 by authors and Scientific Research Publishing Inc.

This work is licensed under the Creative Commons Attribution International License (CC BY). http://creativecommons.org/licenses/by/4.0/

(c) (i) Open Access

\begin{abstract}
Optimal timber production and healthy wild turkey populations can be jointly achieved by balancing cutting cycles, habitat types, and food sources. Expected financial returns from wild turkey management and the habitat required to maintain those returns are estimated. A geographical information system (GIS) is used to illustrate the methodology necessary to distinguish various levels of potential quality turkey habitat, including broad forest conditions across ownerships, like early successional habitat, pine hardwood mixtures, and forest openings, that intermix and combine to form superior wild turkey habitat. A financial analysis framework that considers key financial variables is applied across management regimes to determine net present values, land expectation values, and equivalent annual incomes. Incremental hunting lease revenue from wild turkey hunting leases is shown to impact investment return. The financial framework allows managers to perform sensitivity analyses of costs and revenues to better evaluate management alternatives.
\end{abstract}

\section{Keywords}

Wild Turkey, Habitat Management, Financial Analysis, GIS Analysis

\section{Introduction}

Restoration of the wild turkey (Meleagris gallapavo) is one of the preeminent success stories in wildlife management [1]. The wild turkey has five different subspecies, which are unique to each part of the country: the Eastern, Osceola, Merriam's, Gould's and Rio Grande. Starting the early 1900s, wild turkey populations suf- 
fered declining populations due habitat destruction from rampant logging and uncontrolled hunting pressure. Serious declines peaked in the 1930s and research on how to reverse this decline began in earnest in the 1940s when turkey populations remained only in areas of extensive timberland that were generally inaccessible to humans due to rough topography and a lack of roads [2] [3]. Fortunately, wild turkeys have excellent ability to adapt to their surroundings, as long as that environment includes abundant timberland, limited human contact, and minimal ecological disturbances [1] [3].

Improvement in the declining wild turkey population problem occurred gradually. In 1905 the Lacey Act outlawed interstate transportation of illegally-taken wildlife and in 1937 the Pittman-Robertson established an excise tax on ammunition and sporting goods that was used for wildlife recovery efforts [4]. Aldo Leopold established the field of wildlife management with the publication of the first textbook on the subject in 1933 and the first publication on the biology of the wild turkey was published in 1943 [5] [6].

Trapping wild turkeys was the first real obstacle to reestablishment programs. A major development occurred in the 1950s with cannon and rocket netting for live turkey. Wild turkey were caught, tagged and re-released into a different area with a lower population density. The success of the wild turkey reestablishment is due to four different factors: the rocket and cannon method of live trapping, improved law enforcement, public interest in viewing these birds, and technological advances from interested scientists [7].

All wildlife populations fluctuate, and while wild turkey populations and distributions have increased in many states, some areas have recently seen declines [8]. Reasons for regional population declines include excessive amounts of rain when recently hatched poults are present, an increase in predator populations, and habitat degradation [8]. Moisture is critical for the survival of this species. Too much rain in the springtime can lead to flooding, causing the hens to abandon their nest. An excess of water can also cause rotten eggs, as well as disease among the young turkeys. A lack of water in the summertime, no matter how strong the spring hatch, will almost certainly encourage the population to change location or cause mortality due to stress.

Predators have become an increasing issue in the southeastern United States and more noticeably in South Carolina. Raccoons (Procyon lotor), skunks (Mephitis mephitis), bobcats (Lynx rufus), and coyotes (Canis latrans) seek opportunities to make a wild turkey egg or the turkey itself a meal [9]. Protection from predators is furnished by appropriate vegetation and a variety of different habitats that will sustain the bird. Difficulty in securing hunting locations has resulted in recent declines in the hunter population. This is a double-edged sword as the declining number of hunters can not only help increase wildlife populations, but also lead to less support to help protect the wild turkey population [10].

South Carolina follows the general trend in wild turkey populations. The peak wild turkey harvest by hunters occurred in 2002 and last year's harvest was $25 \%$ less than that level [11]. A major reason for that decline was a negative trend in wild turkey habitat [11]. The wild turkey represents a significant portion of hunting demand in the state; the wild turkey ranks second in hunter demand behind the white-tailed deer (Odocoileus virginianus) in popularity [11]. Hunting has a huge economic impact on states like South Carolina resulting from the manufacture, sale, and provision of hunting outdoor services and products [12]. The economic impact of fishing, hunting, and wildlife viewing on South Carolina's economy is estimated to be roughly $\$ 4$ billion and employment totaling nearly 60,000 jobs [13]. We discuss methods to identify existing and expansion opportunities for turkey habitat using geographic information systems (GIS) in South Carolina and discuss methods to determine the incremental investment value of creating wild turkey habitat.

\section{Habitat}

Turkeys are different from any other game animals in being extremely exclusive in terms of habitat selection and requiring a variety of different habitats in semi-close proximity [1]. There are four specific habitat types in particular. While turkeys can exist in solid young pine plantations, expansive hardwood bottoms, large agricultural environments, and open and burned quail plantation piney woods; an approximately even mix of these four types is the best way to sustain quality turkey populations [14]. Turkeys need different types of habitat for feeding, nesting, brooding, and roosting [15].

Directly or indirectly, moisture seems to be the key to determining the ability of the wild turkey to survive and reproduce [1]. Since the turkey spends the majority of the time on the ground, marshes and other areas of extreme hydric conditions are not suitable for the bird. On the opposite end, it is difficult for turkeys to thrive in areas with little to no water. It should also be noted that the turkey has keen eyesight that it relies on not only for 
feeding and moving around, but also as its primary defense against predators, and it prefers the openness of older timber, whether oaks (Quercus) or pines (Pinus) [16]. The older timber typically is more open and provides feeding, nesting and resting opportunities throughout the day creating a better area for the birds to use.

In the Southeast most of the forestland is in pine production and turkeys will use every aspect of the pine plantations life to their advantage. In the beginning stages of the stand the clear-cut and newly planted seedling are used for food, cover, and brood rearing areas. As the stand matures, turkeys depend on the dense young stand for cover and brooding. After the first thinning, sunlight penetrates through the canopy and contacts the forest floor. When this happens tender tree and brush shoots and a multitude of different insects enter the area and are now targeted by the turkey for food [17]. Poults require nine to twelve grams of spiders and insects a day to meet protein requirements for growth [1].

Thinnings along with periodic prescribed fires make habitat readily available for the turkeys. Periodic harvests, which help improve the areas attractiveness to turkeys, are also financially attractive. As the stand continues to mature and reaches $20-25$ years of age, turkey use of the area for roosting should increase, especially when fire has been used in conjunction with the thinning regimen. Finally the stand is ready to be harvested for the final time and a clear-cut is produced, the cycle repeats again [18].

Wild turkey population declines in South Carolina were due to two major factors. Over the past decade unfavorable weather (wet and cold) during the nesting and brood rearing season affected the population. Timber management activities also played a large role. In the 1980s timber management activities created plenty of early-stage pine plantations that favored turkey populations. Today those same even-aged pine stands are in age classes over ten years of age and those stands do not support increased turkey populations [11].

\section{Changing the Habitat}

Wildlife biologists consider early successional habitat, either natural or man-made, to be the key to the wild turkey success. [19] [20]. Early successional habitat is defined as areas of vigorously growing grasses, forbs, shrubs, and trees which provide excellent food and cover for wildlife, but require natural disturbance to be maintained [19]. Turkeys and other wildlife prefer these areas because of the abundance of combined food and cover. These areas are extremely important in the springtime when nesting and brooding occur. After forests are thinned, the associated ground disturbance and increased sunlight stimulate early succession plant growth, which can be further encouraged with prescribed fire [21]. These areas are not difficult to create, nor are they expensive [22]. This type of habitat can also be created on the edges of fields with light disking every 2 years. Logging decks and truck loading areas, usually 0.5 to 1.0 ha in size, are created as part of timber harvesting activities and produce perfect openings in the forest for brooding and feeding activity [23].

Rarely forests are in ideal form for sustaining a healthy population of turkeys [24]. The transformation of one's property to ideal wildlife habitat, more specifically turkey habitat requires time. Depending on the structure of the existing timber stands and the layout of the tract, it takes years and even decades to develop [25]. The ideal tract needs to have several different components. Mature pine and hardwoods or a mixture of both are ideal for roosting [26]. Small openings throughout the forested area are necessary for early successional species for nesting, feeding, and brooding. The last being smaller agricultural fields commonly known as food plots. These areas are a source of food as well as cover [27].

Trees do not mature overnight and patience is required until a proper stand develops. Turkeys will use an area put into pine production from the week that the harvesting equipment is off the site until the day it returns [28]. A mature, mast-producing forest with the appropriate amount of brood range is just about ideal habitat for wild turkeys [1]. However, throughout the process of the of the stands life, different silvicultural processes make these areas more appealing to turkeys. New clear-cuts and recently planted clear-cuts are a large part of turkeys nesting, brooding, and feeding needs [29].

Professional forestry and wildlife management advice is important in establishing productive wild turkey habitat [30]. Species types, stand age, and the composition of the stand are all important planning considerations [1]. For example, the cutting rotation is extremely important, as it controls all the roost, nesting, and brood habitat and its distribution over time. Staggering the rotations, say, over 5 to 10 year cycles, may be best. Short rotation pine plantations generally do not offer good turkey habitat. In addition to roosting and brooding areas, feeding areas are a necessity for keeping turkeys on a forested property [15]-[17].

Food plots will be an important as they can play an important management role, but are also costly [31]. 
Wildlife food plots can be established by the owner or contracted out through a number of different organizations and companies [32]. If the landowner has the equipment, time, and understanding of how to grow crops, food plot cost can be greatly reduced. Food plots of chufa (Cyperus esculentus var. sativus), clover (Trifolium) or other small grains can provide supplemental food and can attract turkeys [33]. Turkeys will forage on field corn from fall into winter [34]. Corn (Zea mays) also has higher levels of protein than other forms of winter forage such as acorns. The freestanding corn also provides much needed cover when feeding in the winter. Turkeys and other wildlife prefer clover and naked oats (Avena nuda) because of the high protein content. Though it may be more expensive to plant and maintain, chufa is a top wild turkey food and is a major favorite food [35].

The key to identifying wild turkey habitat is to locate forest areas that possess or have the potential to develop transitions of habitat types and food sources. Using GIS, timber stand successional patters can be identified and opportunities to create or protect wild turkey habitat can be established for protection or development. Wild turkey habitat and timber management are compatible, but conversion of existing stands to preferred wild turkey habitat can come at a cost. We use discounted cash flow analysis to determine those incremental costs.

\section{Discounted Cash Flow Analysis}

How does one approach wild turkey management as an investment to supplement timber management? Timber production and wild turkey management are compatible activities. Small changes are made to the standard timber management regime (or activity schedule) with the additional costs incurred for turkey management activities and the extra revenue from the turkey hunting leases or fees added to the value calculation. The simplest approach (and economically sound one) involves incremental or marginal analysis [36]. If only a few costs and revenues involved with timber production change, then the only relevant costs and revenues are the additional (incremental or marginal) ones, and the analysis can evaluate only those costs and revenues. The result will be the incremental value of the wild turkey management [37]. The approach was described recently in the management of waterfowl and it is well-established as a criterion to value wildlife management activities [38] [39]. In its simplest form, incremental analysis can be described as, first, determining the current value of the timber stands as they are now being managed and then, second, determining the current value of the same stands if turkey management was added as an activity. The incremental value is simply the difference between the two. Normally, we'd expect the longer management regime to likely be a cost as the timber rotation was lengthened from shorter one that was probably more optimal.

Cash flow differences can result from simple changes to forest management regimes. Government and private financial incentives can provide cash flows or help reduce costs. Financial incentives may require specific forest management practices. The forest owner's choice of site regeneration can have a large impact on cash flows. The owner has three choices: natural regeneration, machine planting, and hand planting. There are advantages and disadvantages for each. Natural regeneration is free of cost, but can produce great variability in the spacing and number of trees per ha. Hand planting is less costly than machine planting, but produces greater variability in planting quality and the survival rate. Machine planting, the most costly method, involves the use of a bulldozer and special equipment that plants the seedlings in the ground at the correct depth and spacing improving optimum stocking and survival rates.

A complementary analysis technique that can be used in conjunction with incremental analysis to evaluate forest management investments is discounted cash flow analysis or the net present value (NPV) method [40]. It represents the value of the investment today (at year 0) considering interest rates and the timing of the cash flows. Growing timber is a long-term investment, incurring costs and producing revenues throughout the process. The NPV calculation involves subtracting the discounted value of all costs from the discounted value of all revenues. The higher the NPV, the more attractive the investment is [38] [39]. The various formulas and applications that are relevant for wildlife management analysis were thoroughly described in a recent related article [41]. The basic formula for discounting cash flows and determining NPV is:

$$
\mathrm{NPV}=\sum_{t=1}^{N} \frac{R_{t}}{(1+i)^{t}}
$$

where:

$R=$ net revenue in dollars, or revenue minus costs,

$t=$ time in years, 
$I=$ discount or interest rate, expressed as a decimal, and

$N=$ rotation length in years.

In order to illustrate this analysis technique, we used a simple, but realistic, example of a loblolly pine (Pinus taeda) plantation. Scenario one was a typical timber production rotation of 25 years and includes a thinning at around age 15 years. Costs were incurred at year 0 for site preparation, planting occurred in year 1 , herbicide was applied at year 5, and fertilization followed in year 7. Scenario two was managing timber for wild turkeys and the management regime was no different until year 25. Instead of a harvest at year 25, a second thinning occurred and the final harvest followed at age 35 (with more mature timber on the tract). The incremental difference in NPV between the two scenarios involved discounting the different cash flows at years 25 and 35 (since no other cash flows change). Or, the NPV of scenarios one and two could be individually calculated and the difference between the two would be the incremental change.

However, there is an intrinsic problem in comparing the two rotations. The second scenario (35-year rotation) was ten years longer than the first scenario (25-year rotation). The extra ten years in the second scenario represented an opportunity cost in the longer rotation requiring ten more years for completion. Proper financial analysis of timber rotations requires that comparisons be between rotations of equal length. A fair way to compare the two rotations would be, for example, to compare seven 25 -year rotations to five 35 -year rotations. Then 175 years of timber growing is compared to 175 years of timber growing. Two other ways exist to get the comparison on an equal basis. One is the equal annual income (EAI) financial criterion where the NPVs are converted to an equal annual basis. Then a year's worth of value is compared to a year's worth of value. The other method is called land expectation value (LEV). LEV involves calculating the value of the land in perpetual timber rotations. So LEV would give, in our case, the present value of an infinite number of 25-year or 35-year timber rotations. Both rotations would be on a perpetual basis and therefore the comparison would be fair.

Land expectation value (LEV) is a standard calculation in forest valuation [40] [41]. It allows for an efficient way to apply incremental analysis to this problem. It is a type of net present value calculation and determines the value today, considering interest, of growing timber on a forest forever. The result is sometimes called bare land value, as it represents the price one would pay in order to earn the interest rate used in the calculation [42] [43]. If NPV has been calculated without land cost, NPV can easily be converted to LEV using the formula below:

$$
\operatorname{LEV}=\frac{\operatorname{NPV}(1+i)^{r}}{(1+i)^{r}-1}
$$

where:

$\mathrm{LEV}=$ land expectation value,

$r=$ rotation length, in years, and

$i=$ interest rate, expressed as a decimal.

There is a second technique that puts both rotations on an equal footing in terms of time. EAI converts any rotation's NPV into an equal annual equivalent income flow. That would allow for a fair direct comparison of two unequal rotation lengths. EAI can be easily calculated using LEV and the formula below:

$$
\mathrm{EAI}=\operatorname{LEV}(i)
$$

Using LEV or EAI, one could determine the value of a forest stand before turkey management and then the value when turkey management is included. The difference between the two would be the incremental value of adjusting the timber management regime. This same incremental approach has been applied to conservation easement valuation and vegetative competition control in forestry [44] [45]. This incremental cost represents the cost of the foregone opportunity to maximize timber production on all areas of the forest property [46]. It is better described as an opportunity cost. The opportunity cost of lengthening the rotation for wild turkey habitat is calculated by the difference in LEVs as shown below:

$$
\text { Opportunity Cost }=\text { Value }_{\mathrm{w} / \mathrm{o}}-\text { Value }_{\mathrm{w}}
$$

where:

Value $_{\mathrm{w} / \mathrm{o}}=$ LEV or EAI without the turkey regime, and

Value $_{\mathrm{w}}=\mathrm{LEV}$ or EAI with the turkey regime.

While the two financial criteria will produce different numerical results (as they are calculating value for dif- 
ferent timeframes), they will produce consistent results that are mathematically equivalent. We could add the extra revenues and costs of wild turkey management to the longer timber management regime for a full comparison, as opposed to just the impact on timber production. However, if they are added later their impact can be better evaluated. Thus, to enhance clarity, our analysis starts with the impact on timber production and then evaluates the cash flow that results from just wild turkey management.

Wood-related manufacturing is an important component of the economy of the American Southeast, including South Carolina. Timber growing has remained a popular land use due to solid investment returns. Both family forests and large timber investment groups find forestry investment to offer attractive financial returns and a large part of the southern forest will continue to be managed for financial return [47]. An important factor contributing to the financial attractiveness of southern timberland investments has been hunting lease revenue [48]. Shifts in population and demographics have caused demand for quality hunting lands and experiences to increase, along with expected lease revenue [49]. One advantage of hunting lease revenue in the cash flow of a forestry investment is that it is annual revenue that can offset annual costs like property taxes and management fees. Thus, hunting lease revenue is particularly attractive to timberland investors [50].

Hunting leases come with an abundance of options. They are an additional part of the cash flows that must be considered. The landowner has the choice of holding certain hunting rights and granting others, or granting all hunting rights. The advantage of hunting lease revenue is that it occurs in each year, including the early years when revenue might be limited. This produces a major gain in NPV. For an average piece of timberland, one can expect to receive $\$ 20$ to $\$ 70$ per ha for all annual hunting rights in South Carolina. The present value of perpetual annual lease payments can be calculated using the perpetual annual cash flow series formula below [50]:

$$
\text { PV Annual Lease Payments }=a / i
$$

where;

$a=$ value of annual lease payments and

$i=$ interest rate expressed as a decimal.

Using the Annual Lease Payments formula above, present value of those per ha lease payments is $\$ 500$ to $\$ 1750$, at $4 \%$ interest. This high degree of variability in lease prices can be attributed to the amount of effort and money that the landowner contributes to the wildlife enhancement attributes on the property. Some landowners use a "lock and key" method where the lease amount includes all incremental cost that the landowner has incurred from lengthening the rotation to the establishment and maintenance of food plots. More commonly practiced in South Carolina is the "lease as is" method. The landowner does not put any effort into the property and the wildlife enhancement is left solely up to the lessee.

Since the annual hunting lease payment is usually the key financial concern of the forest owner, it makes sense to compare the costs on an equivalent annual basis. We have shown the relationship between the three major discounted cash flow criteria. In particular, we've shown how to ensure equivalency in analysis. Our results will focus on the EAI criterion. This keeps everything on an annual basis, including the hunting lease revenue. Forest owners tend to think in terms of annual lease payments and annual expenses, so this is the logical criterion for this type of incremental analysis.

\section{Methods}

Growing and managing timber can coexist with creating quality turkey habitat, while incurring only modest incremental costs. Certain habitat types produce ideal complementary situations that lend themselves to the joint production of timber and wild turkey. Our methods identify these habitat types and consider the incremental cost of producing wild turkey along with near optimal levels of timber. Remote sensing techniques via aerial photography can aid in identification of areas of very suitable, intermediate suitable, and non-suitable opportunities for wild turkey habitat management [51]. Current aerial photographs were available for the South Carolina Piedmont and forested tracts were evaluated for successional pine habitat characteristics (age, basal area, amount of cover, food source availability, and timber management pattern). Each characteristic can be easily modeled using GIS. All the forest stands identified were field checked to confirm the accuracy of the GIS estimates. Six examples that clearly delineate the visual differences in habitat suitability were selected for the figures described below.

Figure 1 shows six tracts that outline different progressions of suitability in terms of opportunity to jointly practice quality timber management and management for wild turkey. Map 1 and Map 2 (Figure 1) show tracts 


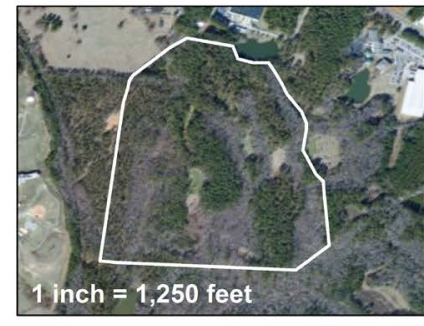

Map 1. Very suitable wild turkey habitat.

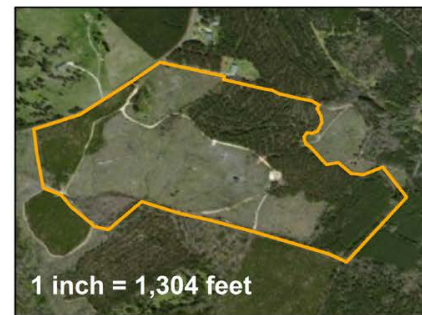

Map 3. Intermediate suitable wild turkey habitat.

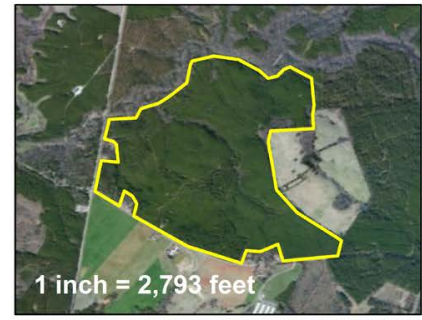

Map 5. Non-suitable wild turkey habitat.

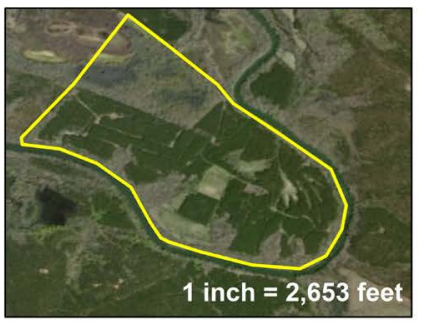

Map 2. Very suitable wild turkey habitat.

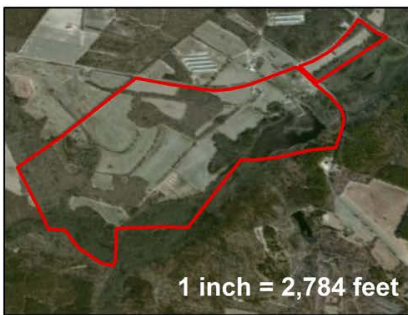

Map 4. Intermediate suitable wild turkey habitat.

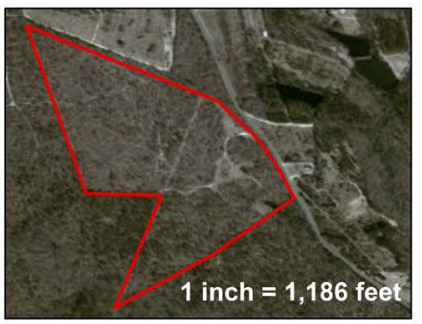

Map 6. Non-suitable wild turkey habitat.

\section{Figure 1. Aerial phototgraphs of various tract types in South Carolina Pied-} mont.

that are currently very suitable for wild turkey habitat and quality timber management. There is a great transition of habitat types and food sources, ranging from managing open food plots, active early successional pine habitat management, and hardwood management. These tracts are the ideal situation a forest owner would want in terms of joint quality timber management and wild turkey habitat management. Map 3 and Map 4 (Figure 1) show tracts with intermediate suitable forest conditions for joint management of wild turkey and timber. But these tracts have excellent potential to become very suitable wild turkey habitat with little effort from the landowner. They have open agricultural fields and some existing pine plantations, as well as hardwood stands. Converting the agricultural fields to early successional pine management and installing small one to two 0.5-1 ha food plots would provide the diversity and quality habitat needed for wild turkey, as well as timber management. Map 5 and Map 6 (Figure 1) show non-suitable tracts for wild turkey habitat. These tracts would require much work to provide the habitat for wild turkey management. Map 5 shows a tract with active timber management implications, but it is not managed as early successional timber management. With proper thinning, burning, and herbicide treatments, as well as the establishment of food plots, the landowner can have very suitable wild turkey habitat conditions. Map 6 shows a tract covered in scrubby oak and mixed pine throughout the property. This is a good example of an opportunity to start a tract with no active wild turkey or timber management and convert it to timber production with wild turkey habitat. By conducting site preparation through herbicide release to kill off the scrubby hardwoods, a scalping and disking activity then establishing a pine plantation under early successional practices, the landowner will have a great starting point to lead to very suitable wild turkey habitat. 
The technique used here involves identification of forested areas, using remote sensing, that are suitable for profitable wild turkey management. A timber management regime (schedule of the timing of all costs and revenues for one timber rotation) is obtained for the forested area [52]. Usually the forested area will need to be managed at a longer rotation to provide suitable habitat (and with more diversity of stand ages). That longer rotation also has a timber management regime. Both are used to calculate EAIs for the two situations: management without turkeys and management with turkeys. The difference between the two will be the incremental cost of managing for the turkeys due to an extended timber management regime.

Three additional revenues and costs must be added to the calculation to include the entire cash flow. First, food plots will likely be required to attract wild turkeys. Establishment and maintenance of these plots will be an ongoing cost. Second, these food plots will be established on what was timberland. A portion of the forest property will no longer be growing timber. This is also a cost. Third, the forest owner expects hunting lease revenue. Hopefully, after considering interest, the value of the incremental hunting lease revenue will exceed the incremental costs.

If done correctly, there should only be a minimal cost for lengthening the rotation period. The key idea is to set up timber harvests on a sequence, to where all the harvests and habitat creation occur periodically; thus, encouraging a diversity of habitat over time. This practice will also give the landowner more frequent harvest revenues making this regime more attractive.

SiMS growth and yield simulator was used to determine the volumes for the thinning and final harvests. This simulator takes into account a multitude of different dimensions using personalized inputs that represent an average stand in the southeast [53]. Site quality is the first input and is a measure of the land's ability to potentially produce timber. Site quality was entered as 70 , which is average for the Southeast. A second parameter is ground competition such as herbaceous (grasses and other weeds) and woody vegetation (unwanted hardwoods and other non-target species). These were both set at a moderate $2 \%$, also typical for the Southeast. Both types of vegetation can prohibit maximum growth by stealing soil nutrients from the target species. These inputs help to calculate accurate basal area, mortality and harvest volumes [52].

A typical pine plantation in the Southeast is on a 25 -year rotation with several silvicultural practices normally performed within the rotation. A wild turkey population management rotation is more typically 35 years long; requiring more silvicultural practices than the traditional rotation, incurring some incremental costs to better suit wild turkeys. A typical 25-year timber production rotation is shown in Table 1 and a typical 35-year wild turkey rotation is shown in Table 2. Often, other revenues from the forest offset annual management and property tax costs; to keep this management regime simple we make that assumption. The harvest volumes in tons for each harvest for both stands were derived from the SiMS stand harvest report. The prices per ton were collected from Timber Mart South [54], using an arithmetic mean or average from the fourth quarter of 2012, 2007 and 2002. This better represents what an average forest owner can expect when selling his timber. Calculations are performed at interest rates of $4 \%, 7 \%$, and $11 \%$. This range of interest ranges should allow any forest owner to compare alternatives using approximately his or her own discount rate. LEV can be easily calculated using the NPV since no land cost was included in this example and EAI can be easily calculated from LEV.

Table 1. Cash flows generated by pine plantation without the turkey regime at various interest rates (per ha).

\begin{tabular}{|c|c|c|c|c|c|}
\hline Year & Item & Amount & $4 \%$ & $7 \%$ & $11 \%$ \\
\hline 0 & Site Prep & $-\$ 247.10$ & $-\$ 247.10$ & $-\$ 247.10$ & $-\$ 247.10$ \\
\hline 1 & Plant & $-\$ 185.33$ & $-\$ 178.20$ & $-\$ 173.21$ & $-\$ 166.96$ \\
\hline 5 & Herbicide & $-\$ 172.97$ & $-\$ 142.17$ & $-\$ 123.33$ & $-\$ 102.65$ \\
\hline 7 & Fertilize & $-\$ 222.39$ & $-\$ 169.00$ & $-\$ 138.49$ & $-\$ 107.12$ \\
\hline 15 & Thin & $\$ 938.99$ & $\$ 521.39$ & $\$ 340.33$ & $\$ 196.26$ \\
\hline \multirow[t]{4}{*}{25} & Harvest & $\$ 11490.28$ & $\$ 4310.20$ & $\$ 2117.07$ & $\$ 845.78$ \\
\hline & NPV & & $\$ 4095.12$ & $\$ 1775.27$ & $\$ 418.21$ \\
\hline & LEV & & $\$ 6553.41$ & $\$ 2176.25$ & $\$ 451.43$ \\
\hline & EAI & & $\$ 262.13$ & $\$ 152.33$ & $\$ 49.65$ \\
\hline
\end{tabular}




\section{Results}

The basic result is the opportunity cost of maintaining wild turkey habitat, rather than intensively managing for maximum timber production. An opportunity cost is the cost of a foregone opportunity. NPVs, LEVs, and EAIs are calculated in Table 1 and Table 2 indicate the value today of the two alternatives at three interest rates. Notice that the better rotation length in terms of maximum NPV depends upon the interest rate. However, when the two options are put on an equal time basis (using either the LEV or EAI criterion), the longer rotation is shown to reduce the value of timber production.

If the forest property is managed for maximum timber production, its EAIs per ha, at $4 \%, 7 \%$, and $11 \%$, respectively, are $\$ 262.13, \$ 152.33$, and $\$ 49.65$ (Table 1). As one would expect, if the same tracts are managed with wild turkey habitat, the value today per ha is reduced. It is decreased, at $4 \%, 7 \%$, and $11 \%$, respectively, to $\$ 245.75, \$ 124.60$, and $\$ 22.92$ (Table 2). The difference between the Table 1 results and the Table 2 results represents the opportunity cost of the wild turkey management regime (without considering food plots or reduced timber growing land). Those differences per ha are, at $4 \%, 7 \%$, and $11 \%$, respectively, $\$ 16.38, \$ 27.73$, and $\$ 26.73$.

Another opportunity cost that must be accounted for is the reduction in timber growing area. Areas managed for wild turkeys may have no timber production or diminished timber production. We make a simple assumption that can be easily adjusted in any similar analysis. We assume a food plot is one-eight ha in size and one food plot per 1.25 ha. This is $10 \%$ of the total forest area in food plots and consistent with game management recommendations [29]. That means the EAIs from the longer rotation should be reduced by $10 \%$ due to decreased timber growing land. These reductions to EAI are, at $4 \%, 7 \%$, and $11 \%$, respectively, $\$ 24.58, \$ 12.46$, and $\$ 2.29$. A third cost is that of the food plots themselves. Food plots are an integral part of holding turkeys on forest land. Depending on what type of forage is planted, food plots may need to be planted on a yearly basis or on a rotation. There is yearly maintenance on these areas no matter what crop is planted. Different alternatives exist depending on limitations of time and money. The least expensive food plot will attract and hold wild turkeys among other wildlife, but not near as well as the high cost food plot. The baseline for the food plots involves planting a single crop of naked oats. It is an annual and needs to be replanted every year. With the correct appli- cation of liquid nitrogen, naked oats will also make a seed head, which is very desirable for all species of wildlife. Stepping up to the intermediate cost food plot will involve planting a mixture of Durana clover and naked oats. In addition to the clover and chufa is naked oats, they are inexpensive to plant and maintain while aiding in the attractiveness of wildlife to the plot. They are relatively high in protein and extremely hardy, tolerating a wide variety of soil compositions found in the southeast [35]-[39].

The high cost food plot, it is more expensive and time-consuming. Corn is the last addition. Where these other crops can all be planted amongst each other by way of broadcast spreading, corn needs to be drilled into the ground by itself. Corn adds dimensions that the other types of forage do not provide. If not cut, corn will stand all year or until the wildlife eat it all or knock it down. Corn also provides cover and in return security for the

Table 2. Cash flows generated by pine plantation with the turkey regime at various interest rates (per ha).

\begin{tabular}{cccccc}
\hline Year & Item & Amount & $4 \%$ & $7 \%$ & $-\$ 1 \%$ \\
\hline 0 & Site Prep & $-\$ 247.10$ & $-\$ 247.10$ & $-\$ 247.10$ & $-\$ 247.10$ \\
1 & Plant & $-\$ 185.33$ & $-\$ 178.20$ & $-\$ 173.21$ & $-\$ 166.96$ \\
5 & Herbicide & $-\$ 172.97$ & $-\$ 142.17$ & $-\$ 123.33$ & $-\$ 102.65$ \\
7 & Fertilize & $-\$ 222.39$ & $-\$ 169.00$ & $-\$ 138.49$ & $-\$ 107.12$ \\
15 & Thin & $\$ 938.99$ & $\$ 521.39$ & $\$ 340.33$ & $\$ 196.26$ \\
25 & Thin & $\$ 3953.64$ & $\$ 1483.08$ & $\$ 728.45$ & $\$ 291.02$ \\
35 & Harvest & $\$ 13096.44$ & $\$ 3318.84$ & $\$ 1226.65$ & $\$ 339.51$ \\
& NPV & & $\$ 4586.84$ & $\$ 1613.30$ & $\$ 202.96$ \\
& LEV & & $\$ 6143.76$ & $\$ 1780.03$ & $\$ 208.35$ \\
\hline
\end{tabular}


turkeys. Chufa, clover and naked oats are all relatively low growing plants, which do not provide the cover aspect. The high cost food plots offers much needed nutrition and cover all year round making it the best choice. Corn, naked oats and chufa are all annuals; meaning they survive for only one season and will need to be replanted on a yearly basis. A smaller area is a perfect place to grow clover. Clover is a perennial and will survive up to three to four years before replanting is absolutely necessary. Durana clover is a genetically modified crop and can tolerate less desirable soil types and drier conditions, making it well-suited for the southeastern regions of the United States. Fertilization and herbicides are necessary for all these crops to be productive [35]-[39].

The wildlife manager will want to develop his or her own food plot system. In general, looking at average costs across the southern United States, estimates for low, intermediate, and high cost food plots are \$130, \$280, and $\$ 450$ per ha of food plot. Recall our assumption of food plots being one-eight ha in size and one food plot allocated per 1.25 ha of forest property, or one-tenth ha of food plot per ha of forest land. Using the intermediate level food plot cost and the ratios above, that comes out to $\$ 28.00$ per ha per year of food plot cost.

The combination of foregone timber growing, food plots, and reduced timber growing area are the total opportunity cost of managing intensive timber production lands as wild turkey habitat. Table 3 reports the final results as EAIs by interest rate. This is to allow for direct comparison of incremental or extra costs (opportunity costs) and potential hunting lese revenue. Certainly, the more intensively a tract is managed for wild turkey, the higher the potential hunting lease revenue [48] [49]. We earlier gave a range of $\$ 20$ to $\$ 70$ per ha as a general range of hunting lease payments in South Carolina. We can directly compare the estimates in Table 3 to this range. Both Table 3 results and the hunting lease revenue are EAI. More expensive tract options would have to earn hunting lease revenue towards the top of the range if the forest owner was to make a profit.

The advantage of Table 3 being expressed in EAI and that this number is directly comparable to annual hunting lease revenue. By its very nature, annual hunting lease revenue is also an EAI. So the forest owner can use the analysis of Table 3 to compare costs directly to anticipated hunting lease revenue. If annual hunting lease revenue equals the EAI of the opportunity cost for any scenario, then the forest owner earns a rate of return equal to that interest rate. Our realistic example shows that rates of return in the $4 \%-11 \%$ range are feasible. We provided a framework for forest owners interested in wild turkey management to incrementally evaluate the components of the investment that will impact rate of return. Our results do not follow a predictable pattern of smoothly decreasing opportunity costs due to the nature of timber volume shifts (in both overall volume and product quality) due to the longer rotation for wild turkey management. However, the results do follow the general trends expected for increasing interest rates.

Carrying the cost of improving timberlands for wildlife reasons does not necessarily have to rest solely on the back of the landowner. If a well-developed management plan is in place and being followed, government funds are available to help offset the cost of some of these silvicultural and wildlife improvements. The Natural Resources Conservation Service offers to help landowners develop habitat for upland wildlife, threatened and endangered species, fish, and other wildlife in South Carolina. Wild turkey habitat is an established concern of federal conservation programs [55]. This government organization can assist landowners who want to improve habitat, including most practices that would be used in both regimes mentioned above. They also offer some additional specialized assistance such as improving early successional habitat and roads [56].

\section{Conclusions}

Habitat that promotes wild turkey populations is on the decline with a push to monoculture timber regimes in the southeast, especially in South Carolina. Financial concerns seem to be the foremost in many minds. The opportunity to create this habitat is abundant across the state as more and more agriculture fields are being converted

Table 3. Opportunity cost of wild turkey habitat on an annual basis by interest rate (per ha).

\begin{tabular}{cccc}
\hline Opportunity Cost & $4 \%$ & $7 \%$ & $11 \%$ \\
Longer rotation & $\$ 16.38$ & $\$ 27.73$ & 12.46 \\
Less timber growing area & 24.58 & 2.29 & 28.00 \\
Food plots (intermediate) & 28.00 & $\$ 68.19$ & $\$ 28.00$ \\
Total opportunity cost & $\$ 68.96$ & $\$ 57.02$ \\
\hline
\end{tabular}


to pine plantations. Managing a timber rotation for wild turkey is very similar to managing strictly for timber production, except it requires a longer rotation. Along with changes to timber management regimes to favor wildlife, food plots can be tremendous assets in attracting wildlife and improving the property value.

Creating the variety of habitat that the turkeys need for everyday life that are in close proximity to each other needs to be the main concern. We have shown that the conversion can be done with little extra cost coming in the form of holding the rotation 10 years longer and establishing food plots throughout the property. The difference in poor turkey habitat and great habitat rests in the 35-year rotation. Some level of food plots are needed to supplement the longer rotation, but the forest owner has options that vary in investment levels.

The most important aspect of this article is the financial framework to perform an incremental analysis of timber management options that attract wild turkeys. The forest owner can use his or her own numbers and assumptions and the framework allows for sensitivity analysis by varying food plot cost and interest rate. The forest owner will have a much better idea of the financial consequences of wild turkey management by first modeling his own property and circumstances to reflect different timber management regimes.

We used realistic financial estimates throughout the analysis and formally modeled the timber parameters. Our results show that very considerable rates of return can be earned from hunting lease opportunities for wild turkey. This should encourage forest owners to consider this valuable financial option.

\section{References}

[1] Dickson, J.G. (Ed.) (1992) The Wild Turkey: Biology and Management. Stackpole Books, Mechanicsburg, PA.

[2] Mitchell, M.D., Kimmel, R.O. and Synders, J. (2011) Reintroduction and Range Expansion of Eastern Wild Turkeys in Minnesota. Geographical Review, 101, 269-284. http://dx.doi.org/10.1111/j.1931-0846.2011.00091.x

[3] Kennamer, J.E., Kennamer, M.C. and Brenneman, R. (1992) History. In: Dickson, J.G., Ed., The Wild Turkey: Biology and Management, Stackpole Books, Mechanicsburg, PA, 6-17.

[4] Cubbage, F.W., O’Laughlin, J. and Bullock, C.C. (1993) Forest Resource Policy. John Wiley \& Sons, Inc., New York.

[5] Leopold, A. (1933) Game Management. Charles Scribner's Sons, New York.

[6] Mosby, H.S. and Handley, C.D. (1943) The Wild Turkey in Virginia: Its Status, Life History and Management. Division of Game and Inland Fisheries, Richmond, VA.

[7] Austin, D.H. (1965) Trapping Turkeys in Florida with the Cannon Net. Proceedings of the Annual Conference of the Southeastern Association of Game and Fish Commissioners, 19, 16-22.

[8] Georgia Wildlife Resources Division (2013) Wild Turkey Fact Sheet. Georgia Wildlife Resources Division, Social Circle, GA.

[9] Palmer, W.E., Priest, S.R., Seiss, R.S., Phalen, P.S. and Hurst G.A. (1993) Reproductive Effort and Success in a Declining Wild Turkey Population. Proceedings of the Annual Conference of the Southeastern Association of Fish and Wildlife Agencies, 47, 138-147.

[10] Rolley, R.E., Kubisak, J.F., Paisley, R.N. and Wright, R.G. (1998) Wild Turkey Population Dynamics in Southwestern Wisconsin. Journal of Wildlife Management, 62, 917-924. http://dx.doi.org/10.2307/3802543

[11] Ruth, C. (2013) 2013 South Carolina Turkey Harvest Report. South Carolina Department of Natural Resources, Turkey Research \& Management Project, Columbia, SC.

[12] Southwick Associates (2012) Hunting in America: An Economic Force for Conservation. National Shooting Sports Foundation, Newtown, CT.

[13] Woodward, D.P. and Guimaraes, P. (2009) Underappreciated Assets: The Economic Impact of South Carolina's Natural Resources. University of South Carolina, Moore School of Business, Columbia, SC.

[14] DeVos, T. (2003) Successful Turkey Management, Part 1 of 3: Pine Woodland Enhancement. Wildlife Trends, 3, 5-7.

[15] West, B. (2005) Forest Management for Wild Turkeys, Bulletin 2033. Mississippi State University Extension Service, Mississippi.

[16] Smith, M. (2010) Wild Turkey Management in Alabama, ANR-0512. Alabama Cooperative Extension System, Huntsville.

[17] USDA Natural Resources Conservation Service (1999) Wild Turkey, Fish and Wildlife Habitat Management Leaflet Number 12. USDA Natural Resources Conservation Service, Washington DC.

[18] Miller, D.A., Hurst, G.A. and Leopold, B.D. (1999) Habitat Use of Eastern Wild Turkeys in Central Mississippi. Journal of Wildlife Management, 63, 210-222. http://dx.doi.org/10.2307/3802503 
[19] Masters, R., Stewart, M. and Bidwell, T. (1998) Wild Turkey, Publication L-269, Forest Stewardship Wildlife Management Notes No. 3. Oklahoma State University Cooperative Extension Service, Stillwater.

[20] Harper, C.A. (2007) Strategies for Managing Early Succession Habitat for Wildlife. Weed Technology, 21, $932-937$.

[21] Burger Jr., L.W. (2006) Creating Wildlife Habitat through Federal Farm Programs: An Objective-Driven Approach. Wildlife Society Bulletin, 34, 994-999. http://dx.doi.org/10.2193/0091-7648(2006)34[994:CWHTFF]2.0.CO;2

[22] Smith, E.T. (2007) Early Successional Habitat, Fish and Wildlife Habitat Management Leaflet Number 41. USDA Natural Resources Conservation Service, Washington DC.

[23] Thompson III, F.R. and DeGraff, R.M. (2001) Conservation Approaches for Woody, Early Successional Communities in the Eastern United States. Wildlife Society Bulletin, 29, 483-494.

[24] Schorger, A.W. (1966) The Wild Turkey: Its History and Domestication. University of Oklahoma Press, Norman.

[25] Gustafson, E.J., Parker, G.R. and Backs, S.E. (1994) Evaluating Spatial Pattern of Wildlife Habitat: A Case Study of the Wild Turkey (Meleagris gallapavo). American Midland Naturalist, 131, 24-33. http://dx.doi.org/10.2307/2426605

[26] Holbrook, N.T., Vaughn, M.R. and Bromley, P.T. (1987) Wild Turkey Habitat Preferences and Recruitment in Intensively Managed Piedmont Forests. Journal of Wildlife Management, 51, 182-187. http://dx.doi.org/10.2307/3801652

[27] Holder, B.P. (2006) Survival, Habitat Use, and Nest-Site Characteristics of Wild Turkeys in Central Mississippi. M.S. Thesis, Mississippi State University, Starkville, Mississippi.

[28] Felix III, A.C., Sharik, T.L. and McGinnes, B.S. (1986) Effects of Pine Conversion on Food Plants of Northern Bobwhite Quail, Wild Turkey, and White-Tailed Deer in the Virginia Piedmont. Southern Journal of Applied Forestry, 10, 47-52.

[29] Yarrow, G. (2009) Biology and Management of Eastern Wild Turkey, Fact Sheet 35. Clemson University Forestry and Natural Resources Extension, Clemson, SC.

[30] Larson, C.J. (2004) Modeling Forest Transition Pathways for Decision Making in Private Forestry. M.S. Thesis, University of Missouri, Columbia.

[31] Harper, C.A. (2008) A Guide to Successful Wildlife Food Plots: Blending Science with Common Sense, Publication 1769. University of Tennessee Extension, Knoxville.

[32] McPeake, R., Roberg, R., Self, C. and Long, D. (2010) Establishing Wildlife Food Plots, FSA 9092. University of Arkansas Division of Agriculture, Little Rock.

[33] Billingsley, E. (2007) Planting a Wild Turkey Food Plot. University of Illinois Extension, Urbana-Champaign.

[34] Porter, W.F., Tangen, R.D., Nelson, G.C. and Hamilton, D.A. (1980) Effects of Corn Food Plots on Wild Turkeys in the Upper Mississippi Valley. Journal of Wildlife Management, 44, 456-462. http://dx.doi.org/10.2307/3807977

[35] National Wild Turkey Federation (2013) Chufa Addiction: All You Need to Know About the Food Source Wild Turkeys Can't Resist. National Wild Turkey Federation, Edgefield, SC.

[36] Straka, T.J. (2005) Forest Products Decisions: Comparing Investment Alternatives. Forest Products Equipment, 13, 21-24.

[37] White, J.A., Case, K.E. and Pratt, D.B. (2012) Principles of Engineering Economic Analysis. 6th Edition, John Wiley \& Sons, Inc., New York.

[38] Clardy, R.Z., Smathers Jr., W.M. and Straka, T.J. (2012) The Incremental Investment Value of Waterfowl Impoundments in the Upstate of South Carolina. Wildlife Biology in Practice, 8, 9-19.

[39] Verburg, E.A., Charbonneau, J.J., Mangun, W.R. and Llewellyn, L.G. (1987) The Importance of Fish and Wildlife Values to the Profession. In: Decker, D.J. and Goff, G.R., Eds., Valuing Wildlife: Economic and Social Perspectives, Westview Press, Boulder, CO, 49-59.

[40] Bullard, S.H. and Straka, T.J. (1998) Concepts in Forest Valuation and Investment Analysis. Forestry Suppliers, Jackson, MS.

[41] Straka, T.J., Bullard, S.H. and Dubois, M.R. (2001) Introduction to Forestry Investment Analysis, Part I: Basic Investment Characteristics and Financial Criteria. Forest Landowner, 60, 9-14.

[42] Straka, T.J., Bullard, S.H. and Dubois, M.R. (2002) Introduction to Forestry Investment Analysis, Part II: Taxes, Inflation, and Other Issues. Forest Landowner, 61, 39-44.

[43] Straka, T.J. and Bullard, S.H. (1996) Land Expectation Value Calculation in Timberland Valuation. Appraisal Journal, 64, 399-405.

[44] Singleton, C.N., Straka, T.J. and Askew, G.R. (2001) Valuation of Conservation Easements on Forestland. Real Estate Review, 32, 52-58.

[45] Straka, T.J. (2010) Financial Breakeven Point for Competition Control in Longleaf Pine (Pinus palustris Mill) Rees- 
tablishment. New Forests, 40, 165-173. http://dx.doi.org/10.1007/s11056-010-9191-2

[46] Straka, T.J. and Bullard, S.H. (2006) An Appraisal Tool for Valuing Forest Lands. Journal of the American Society of Farm Managers and Rural Appraisers, 69, 81-89.

[47] Wear, D.N. and Greis, J.G. (2012) The Southern Forest Futures Project: Summary Report, General Technical Report SRS-168. USDA Forest Service, Southern Research Station, Asheville, NC.

[48] Baen, J.S. (1997) The Growing Importance and Value Implications of Recreational Hunting Leases to Agricultural Land Investors. Journal of Real Estate Research, 14, 339-414.

[49] Zhang, D., Hussain, A. and Armstrong, J.B. (2006) Supply of Hunting Leases from Non-Industrial Private Forest Lands in Alabama. Human Dimensions of Wildlife, 11, 1-14. http://dx.doi.org/10.1080/10871200500470910

[50] Straka, T.J. and Greiner, T.S. (2011) Contribution of Wildlife to the Value of U.S. Southern Forestland. Journal of the American Society of Farm Managers and Rural Appraisers, 74, 23-32.

[51] Donovan, M.L., Robe, D.L. and Olson Jr., C.E. (1987) Use of Geographic Information Systems to Develop Habitat Suitability Models. Wildlife Society Bulletin, 15, 574-579.

[52] Bettinger, P., Boston, K., Siry, J.P. and Grebner, D.L. (2009) Forest Management and Planning. Academic Press, Burlington, MA.

[53] Pretzsch, H. (2009) Forest Dynamics, Growth and Yield: From Measurement to Model. Springer-Verlag, Berlin.

[54] Timber Mart-South (2013) Timber Mart-South. University of Georgia, Center for Forest Business, Athens.

[55] Weldon, A., Gray, R., Hoefner, F., Redlin, B. and Boshoven, J. (2010) Conserving Habitat through the Federal Farm Bill: A Guide for Land Trusts and Landowners. Defenders of Wildlife, Washington DC.

[56] Straka, T.J., Kilgore, M.A., Jacobson, M.G., Greene, J.L. and Daniels, S.E. (2007) Influence of Financial Incentive Programs in Sustaining Wildlife Values. Human Dimensions of Wildlife, 12, 197-199. http://dx.doi.org/10.1080/10871200701323173 
Scientific Research Publishing (SCIRP) is one of the largest Open Access journal publishers. It is currently publishing more than 200 open access, online, peer-reviewed journals covering a wide range of academic disciplines. SCIRP serves the worldwide academic communities and contributes to the progress and application of science with its publication.

Other selected journals from SCIRP are listed as below. Submit your manuscript to us via either submit@scirp.org or Online Submission Portal.
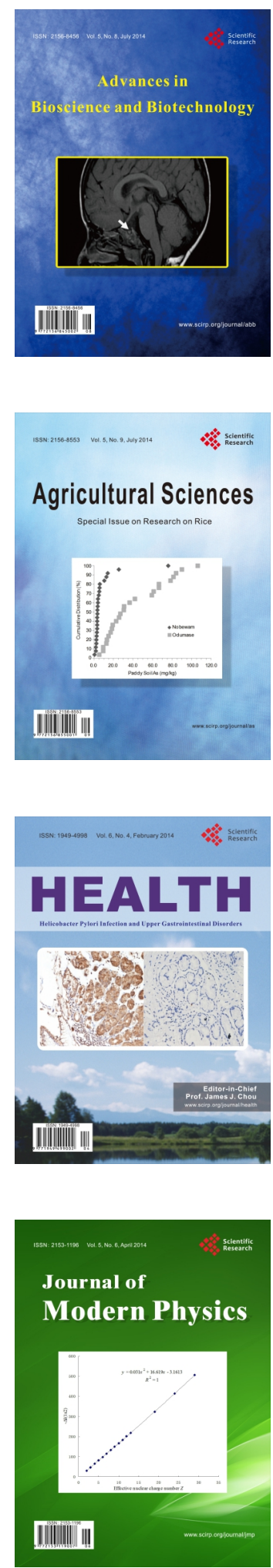
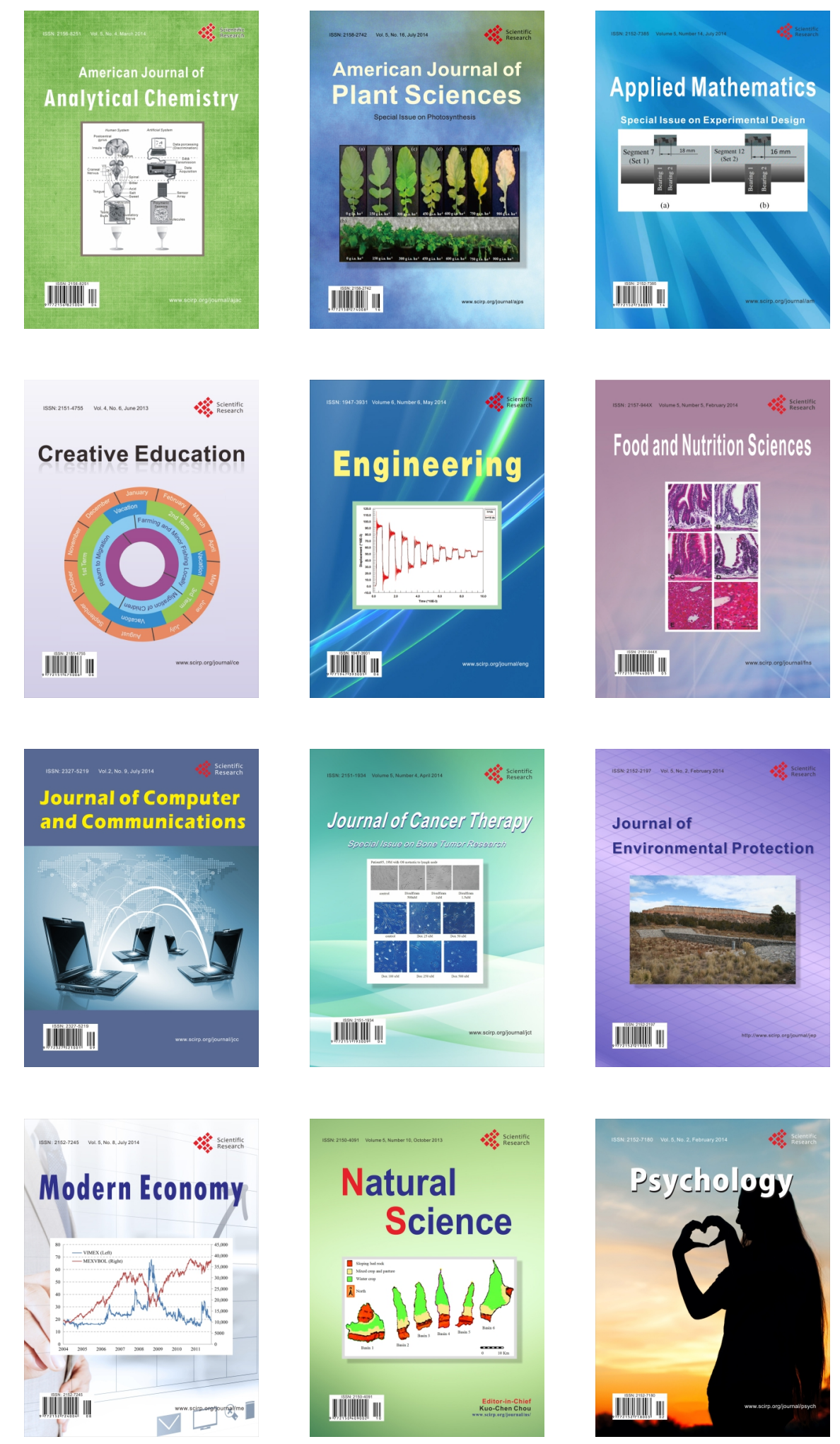